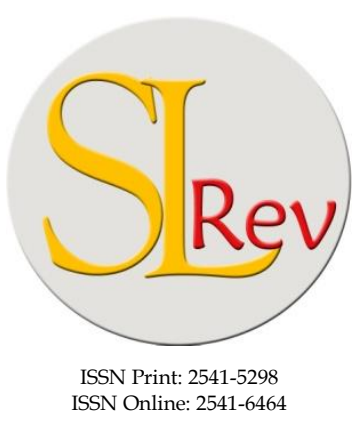

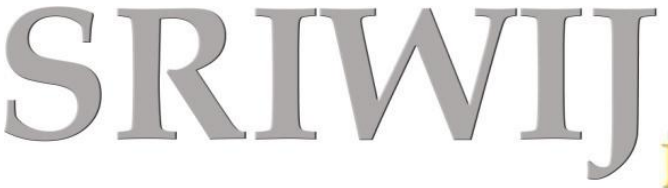
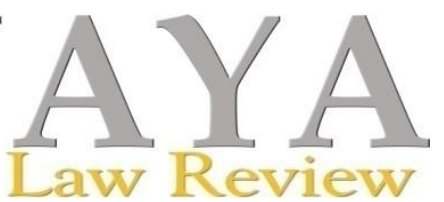

Editorial Office: Faculty of Law, Sriwijaya University Jalan Srijaya Negara, Palembang, South Sumatra 30139, Indonesia. Phone: +62711-580063Fax: +62711-581179 E-mail: sriwijayalawreview@unsri.ac.id | sriwijayalawreview@gmail.com Website: http://journal.fh.unsri.ac.id/index.php/sriwijayalawreview

\title{
CLIMATE CHANGE AND COMMUNITY ENVIRONMENTAL CONFLICTS: ARE THEY CORRELATED?
}

\author{
Achmad Romsan ${ }^{1}$, Farida Ali $^{2}$, Akhmad Idris $^{3}$, Adrian Nugraha ${ }^{4}$, Nurhidayatuloh $^{5}$ \\ and Suzanna Mohamed Isa ${ }^{6}$
}

\begin{abstract}
Climate change and global warming affect major change in freshwater availability and season uncertainty which hamper all part of the globe. Although the phenomenon is not new but it needs concerns from all the government of States around the world to address the problem. If notthe drought and water shortages will directly and indirectly be the world problem and finally will ignite conflict over resources.Pollution and environmental degradation will also affect the sustainability of community's economic activities. In Indonesia, since the enforcement of the first Environmental Management Act of 1982 up to the third Environmental Management Act of 2009, there have been forty one conflicts involving community and industries and palm plantation companies. All the conflicts are brought before the courts. Herein, industries and plantations are blamed for responsible for river water pollution and environmental degradation. Unfortunately, there is very little information in Indonesia obtained from the research reports, journals, news papers, magazines whether climate change and global warming also responsible for the occurrence of community environmental conflict. From the second data sources obtained from outsite Indonesia it is found that there is a link between climate change and community environmental disputes. The objectives of this paper tryto examine whether the cases submitted and solved by the District Courtsalso have some connection with the climate change phenomenon. Other objectives are to recommend to the Government of Indonesia to strengthen the existing regulations dealing with the climate change.
\end{abstract}

Keywords : climate change; global warming; community environmental disputes; pollution; environmental degradation.

\section{ARTICLE HISTORY:}

Received:

Dec 20, 2016; Reviewed: Dec 30, 2016

Accepted:

Jan 17, 2017; Published: Jan 31, 2017.

${ }^{1}$ Faculty of Law, Sriwijaya University, Palembang-South Sumatera, Indonesia

Jln. Raya Palembang - Prabumulih Km.32

Ogan Ilir Indralaya

E-mail:aromsan@fh.unsri.ac.id;

aromsan@yahoo.com
${ }^{2}$ Faculty of Law, Sriwijaya University, Palembang-South Sumatera, Indonesia

Jln. Raya Palembang - Prabumulih Km.32 Ogan Ilir Indralaya

E-mail:umikrachmi@gmail.com

${ }^{3}$ Faculty of Technick, Sriwijaya University, Palembang-South Sumatera, Indonesia

Jln. Raya Palembang - Prabumulih Km.32 Ogan Ilir Indralaya

E-mail:a.idrs@yahoo.co.id

${ }^{4}$ Faculty of Law, Sriwijaya University, Palembang-South Sumatera, Indonesia

Jln. Raya Palembang - Prabumulih Km.32 Ogan Ilir Indralaya 
E-mail: nugrahadrie@gmail.com

${ }^{5}$ Faculty of Law, Sriwijaya University, Palembang-South Sumatera, Indonesia

Jln. Raya Palembang - Prabumulih Km.32 Ogan Ilir Indralaya

E-mail:hidate.ugm@gmail.com

${ }^{6}$ Faculty of Law, University Kebangsaan Malaysia, 43600 UKM Bangi, Selangor, Malaysia

E-mail:zie@ukm.edu.my

\section{INTRODUCTION}

Up to 2009, the Indonesian Environmental Acts have undergone changes thrice ${ }^{1}$ and within 27 years (1982- 2009), there had been at least 40 environmental disputes between the communities and the industries and plantations. Pollution and environmental degradation were blamed to be the cause of conflict. Pollution and environmental degradation impact on the disruption of the economic activity of the community. Bringing the disputes to the court is not the only alternative to be recommended for the judicial decisions has weaknesses ${ }^{2}$ and power imbalanced between actors makes it difficult to reach environmental justice. ${ }^{3}$ Conversely, looking at the 40 environmental disputes above, the court seems is the only alternative for solving the disputes. Consequently, this situation is in contra-

1 The 1982 EMA No.4 on The Basics Provisions on Environmental Management replaced by The 1977 EMA No. 23 on Environmental Management and the last one is The 2009 EMA No. 32 of 2009 on The Protection and Environmental Management.

2 S. Stec, "Environmental Justice through courts in countries in economic transition." In Jonas Ebbesson and Phoebe Okowa (Ed), Environmental Law and Justice in Context, Cambridge University Press, 2009, pp 158-175.

3 J. Darpö, "Environmental Justice through Environmental Courts? Lessons Learned from the Swedish Experience." In Jonas Ebbesson and Phoebe Okowa (Ed), Environmental Law and Justice in Context, Cambridge University Press, New York, 2009. pp 179- 210. dictory to what had been mandated by the 2009 Law No. 23 on the Protection of and the Management of the Environment ${ }^{4}$ which requires the party to employ mediation first before deciding to bring their case to the court. ${ }^{5}$ The effectiveness of using mediation for environmental disputes is encouraged by the EMA 2009. Many scholars such as Crowfoot and Wondollect, $^{6}$ Bulland, ${ }^{7}$ Allen, ${ }^{8}$ Nicholson, ${ }^{9}$ Straus, ${ }^{10}$ Crable $^{11}$ and Carpenter ${ }^{12}$ suggested that mediation is best mechanism to solve environmental conflict. The United States, for example, is the country to which mediation has been used effectively to solve many environmental disputes. ${ }^{13}$

Unfortunately, when one looks at the 40 cases above, industries and palm plantations are blamed to be the contributor for environmental pollution and environmental degradation. Whilst many studies concluded

4 Hereinafter cited as The EMA 2009.

5 See: Art. 84 (3) The 2009 Law No. 23 (State Gazette 2009 No. 140).

6 James E. Crawfoot \& Julia M. Wondolect, Community Involvement in Conflict Resolution, Island Press, Washington DC, Covelo California, 1990.

7 Robert D. Bulland, Dumping in Dixie: Race, Class, Environmental Quality, $3^{\text {rd }}$ Edition, West View Press, 2000.

8 Petter T. Allen, "Pubic Participation in Resolving Environmetnal Disputes and the Problem of Representation," 9 Risk, 1998. p 297.

9 D.F. Nicholson, Environmental Disputes Resolution in Indonesia, KITLV Press, Leiden, 2009.

10 D. B. Straus, 1978, Mediating Environmental Disputes,) 33 (4) Arbitration Journal, pp 5-8.

11 S. Crable, 1993, ADR: A Solution for Environmental Disputes, 48 (1) Arbitration Journal, pp 24-36.

12 S. L. Carpenter,1982,Managing Environmental Disputes, 8 (2/3) Peace \& Change.

13 A. R. Talbot, Settling Things: Six Case Studies in Environmental Mediation, Published by the Conservation Foundation and the Ford Foundation, $2^{\text {nd }}$ printing 2004. 
that pollution is not the only factor to cause the conflict but climate change have also contributed to trigger the community environmental conflicts. This argumentation can be seen in the studies conducted by, for example, Klare $^{14}$ is of the opinion that climate change may cause resource war. Renner $^{15}$ discussed climate change may cause soil conflict. Thus, climate uncertainty may lead to long drought or long rainy season and change the cycle livelihoods of farmers and fishermen. In Indonesia, there is a study conveyed by Falconer, Glenday, Rosenberg and Wilkinson ${ }^{16}$ discussed about the commitment of the government of Indonesian to boosting economic growth and also reduces the risk of climate change by the reduction of greenhouse gas emissions by $26 \%$ by 2020 .So this far, in Indonesia, there is no study or research which analyze whether in the community environmental dispute, climate change is one of the triggered factor responsible to cause pollution and environmental degradation.

In term of climate change and environmental conflict, there is study conducted by Rleigh and Urdal ${ }^{17}$ which had been proven

14 Klare, M.T, Resource Wars: The New Landscape of Global Conflict. Metropolitan, New York, 2001.

15 Rener, M. Fighting for Survival: Environment Decline, Social Conflict, the New Age of Insecurity. EnvironmentalAlert Series. Norton, New York, 1996.

16 Angela Falconer, Skye Glenday, Anja Rosenberg, and Jane Wilkinson, Pemetaan Pendanaan Publik untuk Perubahan Iklim di Indonesia, Climate Policy Initiative, July 2014, http://climate policyinitiative.org/publication/pemetaan-pen danaan-publik-untuk-perubahan-iklim-diindonesia/. (retrieved: Dec 18, 2016).

17 Clionadh Raleigh, Henrik Urdal,2007,Climate Change, Environmental Degradation and Armed Conflict,Political Geography 26. pp 674-694. the correlation of environmental conflict and the global climate change. Clime changes issues and environmental security was discussed by Levy, ${ }^{18}$ Barnett, ${ }^{19}$ and Gleditsch. ${ }^{20}$ The later scholars suggested that all the States should have been able to anticipate the impact of climate change with the community conflict. Similar study also conducted by Marcia, ${ }^{21}$ also Mahe, Lienou, Descroix, Bamba, Paturel, Laraque, Meddi, Habaieb, Adeaga, Dieulin, Chahnez Kotti and Khomsi. ${ }^{22}$ So this far there is very little information regarding the study on the correlation of the issue of climate changes to the occurrence of community environmental disputes in Indonesia.

The objectives of this paper are to examine, from the secondary sources such as the decisions of the courts and also the court cases obtained from the books, research report and journals. In the context of climate change and the environmental disputes, the analysis stresses on the examination on the background of the disputes, when the disputes occur and also the verdicts of the district court. The writer also will examine the extent of the

18 Levy, M. 1995. Is the Environment A National Security Issue?, International Security, 20(2). pp 35-62.

19 Barnett, J. Security and Climate Change. Working Paper 7. Tyndall Centre for Climate Change Research, Norwich. 2001.

20 Gleditsch, N. P., 1998, Armed Conflict and the Environment, Journal of Peace Research, 35(3), pp 381-400.

21 Creary Marcia, 2013, Impact of Climate Change on Coral Reefs and the Marie Environment, $U N$ Chronicle. Vol. 50 Issue 1, pp24-27.

22 Mahe, G.; Lienou, G.; Descroix, L.; Bamba, F.; Paturel, J. E.; Laraque, A.; Meddi, M.; Habaieb, H.; Adeaga, O.; Dieulin, C.; Chahnez Kotti, F.; Khomsi, K, 2013, The rivers of Africa: Witness of Climate Change and Human Impact on the Environment, Hydrological Processes. Vol. 27 Issue 15, pp 2105-2114. 
Government of Indonesia anticipates the impact of the climate change on social life, economy and law. Prior coming to the discussion, this paper will start with urgent concern of climate change for Indonesia.

\section{ANALYSIS AND DISCUSSION}

In Indonesia, there is no follow-up studies on the effect of climate change on the community environmental disputes except the review of the global conservation organization $^{23}$ where climate change in Indonesia has impacted on the annual rainfall whichalready down by 2 to 3 per cent, and the seasons are changing. As a matter of fact, Indonesia, geographically, is one of the most vulnerable countries to the impact of climate change. This is because Indonesia is a country with high population density and high levels of biodiversity, and has 80,000kilometres of coastline and 17,500 islands big and small. In the paper presented by Michael Case, Fitrian Ardiansyah, Emily Spector ${ }^{24}$ that the climate change has impact on water availability, sealevel rise, biodiversity and ecosystem services, human health and vulnerability and adaptation.

Although phenomenon of climate change has occur long time ago, ${ }^{25}$ and is not considered as the $21^{\text {th }}$ the world problem, the Government of Indonesia has anticipated the

23 "Climate Change in Indonesia - Implications for Humans and Nature," in http://www.globalgreenhouse-warming.com/climate-change-inIndonesia.html. (retrieved: Dec 19, 2016).

24 Michael Case, Fitrian Ardiansyah, Emily Spector, Climate Change in Indonesia Implications for Humans and Nature, WWF(in http://assets. panda.org/downloads/ino...) (retrieved: Jan 12, 2017).

25 Thomas J. Crowley, 2000, Causes of Climate Change Over the Past 1000 Years, Science, p 289 $\& 270$. impact of the climate change by enacting several laws and regulations such as The 2004 Law No. 17 on the Ratification of the Kyoto Protocol to the United Nations Framework Convention On Climate Change (Kyoto Protocol Framework Convention on United Nations Regarding Climate Changes), The 2009 Law No. 32 on the Protection of and the Management of the Environment, The 2001 Government Regulation No. 4 on controlling the damage and pollution of the environment or relating to forest or land fires, The 2004 Law No. 19 on the Forestry.

At international level, there found some studies conducted by Jiang and Zhang, ${ }^{26}$ Wentz, ${ }^{27}$ Yang; Sei-Ichi; Hiromichi and Toru. ${ }^{28}$ Unfortunately, these studies only examined the issues of climate change to agriculture and marine environment. To this far, industry and plantation are always seen as the actors or contributors to pollution and environmental degradation. Environmental conflicts are the resultant of climate change and effect on the uncertainty in the climate in Indonesia, such as prolonged drought and erratic rainfall.

26 Chong Jiang and Linbo Zhang, 2015, Climate Change and Its Impact on the Eco-Environment of the Three-Rivers Headwater Region on the Tibetan Plateau, China, Int. J. Environ. Res. Public Health, 12, pp12057-12081; doi: 10.3390/ijerph121012057. (retrieved: Dec 19, 2016).

27 Wentz, Jessica, 2015, Assessing the Impact of Climate Change on the Built Environment, Environmental Law Reporter: News \& Analysis. Vol. 45 Issue 11, pp11015-11031. (retrieved: Dec 19, 2016).

28 Liu, Yang; Saitoh, Sei-Ichi; Igarashi, Hiromichi; and Hirawake, Toru, 2014, The Region$\mathrm{Al}$ Impacts of Climate Change on Coastal Environments and The Aquaculture of Japanese Scallops in Northeast Asia: Case Studies from Dalian, China, and Funka Bay, Japan, International Journal of Remote Sensing., Vol. 35 Issue 11/12, pp 4422-4440. 
In regard to the issue above, there are two international conferences on climate change The Earth Summit in Rio de Janeiro, Brazil in 1992. The Summit has successfully produced the commitment of the world com-Imunity to adopt an agreement on climate change through the United Nations Framework Convention on Climate Change) (UNFCCC). This commitment is urgent since the climate change has affected the whole parts of the world including Indonesia. The IPCC data (Intergovernmental Panel on Climate Change $)^{29}$ reported that the world within the period of 100 years, the global average of the world climate, increased $0.74^{\circ} \mathrm{F} \pm 0.18{ }^{\circ} \mathrm{C}(1.33 \pm$ $0.32^{\circ} \mathrm{F}$ ) which effect on the elevation of sea level in all parts of the world. For example, in the $21^{\text {st }}$ century, the sea level has increased from 9-88 $\mathrm{cm}$ (4-35 inches). If the increase of sea level reaches 40 inches $(100 \mathrm{~cm})$ therefore it will sink $6 \%$ of territory of the Netherland, 17, 5\% of Bangladesh. ${ }^{30}$ Furthermore, the coastal area of Indonesia, where the level of the territory is the same with the above countries will have hampered the same problem. Legal consequence is it will also affect the territorial border of Indonesia as a whole.

The significant impact of climate change is the reduction of the freshwater availability which the source of life of all creatures including human beings, the fighting of resources which ignites conflict

29 Pebriansyah Ariefana, "Dampak Perubahan Iklim di Indonesia yang Sudah Terasa" (30 October 2015), avalaible from: http://www.suara.com/ news/2015/10/ 30/060600/ dampak-perubahaniklim-di-indonesia-yang-sudah-terasa. (retrieved: Jan 29, 2016).

30 Pebriansyah Ariefana. Note 29. among or between the states. Rleigh adn Urdal mentioned that: ${ }^{31}$

Climate change is expected to bring about major change in freshwater availability, the productive capacity of soils, and in patterns of human settlement. However, considerable uncertainties exist with regard to the extent and geographical distribution of these changes. Predicting scenarios for how climate-related environmental change may influence human societies and political systems necessarily involves an even higher degree of uncertainty. The direst predictions about the impacts of global warming warn about greatly increased risks of violent conflict over increasingly scarce resources such as freshwater and arable land.

One should notice that the world population explosion within the next 15 years will also affect the reduction on the renewable resources, freshwater availability, the size of agricultural areas, forest areas, and also some species will also reduce and dwindled or distinct. ${ }^{32}$ Consequently, there should have been environmental conflicts in many parts of the world. There are six types of environmental change were identified as plausible causes of violent intergroup conflict. Those types are greenhouse-induced climate change; stratospheric ozone depletion; degradation and loss of good agricultural land; degradation and removal of forests; depletion and pollution of fresh

31 Clionadh Raleigh, Henrik Urdal,2007,Climate Change, Environmental Degradation and Armed Conflict,Political Geography 26 pp674-694.

32 Thomas F. Homer-Dixon,1994,Environmental Scarcities and Violent Conflict: Evidence from Cases,Peace and Conflict Studies Program, University of Toronto, International Security, Vol. 19, No. I, pp 5-40. 
water supplies; and depletion of fisheries. ${ }^{33}$ Population growth and resource scarcity are as causes of the conflict between the Sandinista government and the Miskito Indians in Nicaragua. ${ }^{34}$

Although in Indonesia, there is little information on the studies dealing with the community environmental disputes as a result of scarcity of the resources with the climate change. In fact, community environmental disputes in Indonesia have emerged on the surface since the application of the EMA 1982, the EMA 1997 and the EMA 2009 is they are provided for in the following Table I.

The Table I illustrates that all community environmental dispute start from pollution and environmental degradation, which eventually affect the people's livelihood. Most of the victims are poor peasants, whose livelihood depends on farming activities.
The climate uncertainty as the impact of global climate change may be long drought and long wet season. Nevertheless, it may happen the long drought season and short wet season, vice versa. The community in general and the farmers in particular use the river water for daily consumption as well as the industry uses the river as waste disposal. The long drought may cause the volume of river water reduced. As a result the water cannot neutralize the pollutants that dispose to the river. The correlation of global climate change will be easily understood if to illustrate through the diagram 1.

In other words, resources scarcity may end up in the conflict among or between the stakeholders whose dependence on the water or the river. The figure 1 bellow explains that dependency. ${ }^{35}$ 
Table I

Community environmental disputes in Indonesia as of 1982-2004

\begin{tabular}{|c|c|c|c|}
\hline No. & Disputes & Year & $\begin{array}{c}\text { Litigation (L) /Non-Litigation(NL) } \\
\text { (Médiation) }\end{array}$ \\
\hline 1. & PT. Inti Indorayon Utama Case & 1989 & $\mathrm{~L}$ \\
\hline 2. & PT. Pupuk Iskandar Muda & 1989 & $\mathrm{~L}$ \\
\hline 3. & Samidun Sitorus cs v PT. Inti Indorayon & 1989 & $\mathrm{~L}$ \\
\hline 4. & PT. Sarana Surya Sakti Case & 1991 & $\mathrm{~L}$ \\
\hline 5. & PT. Muara Jaya & 1991 & $\mathrm{~L}$ \\
\hline 6. & Tapak River Case & 1991 & NL \\
\hline 7. & Tembok Dukuh v PT. SSS Case & 1991 & NL \\
\hline 8. & Sulae Case & 1992 & $\mathrm{~L}$ \\
\hline 9. & Tyfountext (Solo) & 1992 & NL \\
\hline 10. & Siak River & 1992 & NL \\
\hline 11. & Sambong River (Batang) & 1993 & NL \\
\hline 12. & Singosari SUTET Case & 1994 & $\mathrm{~L}$ \\
\hline 13. & Reafforestation Fund (IPTN) Case & 1994 & $\mathrm{~L}$ \\
\hline 14. & Sibalec (Yogyakarta) & 1994 & NL \\
\hline 15. & Naga Mas (Central Java) & 1994 & NL \\
\hline 16. & Ciujung River (West Java) & 1995 & NL \\
\hline 17. & Samitex (Yogyakarta) & 1995 & NL \\
\hline 18. & Surabaya River Case & 1995 & $\mathrm{~L}$ \\
\hline 19. & Freeport Case & 1995 & $\mathrm{~L}$ \\
\hline 20. & Sari Morawa Case & 1996 & $\mathrm{~L}$ \\
\hline 21. & Reafforestation Fund (PT. Kiani Kertas) & 1997 & $\mathrm{~L}$ \\
\hline 22. & Indo Acidatama (Central java) & 1997 & NL \\
\hline 23. & Exponent 66 v APHI & 1998 & $\mathrm{~L}$ \\
\hline 24. & Laguna Mandiri & 1998 & $\mathrm{~L}$ \\
\hline 25. & WALHI v PT. Pakerin & 1998 & $\mathrm{~L}$ \\
\hline 26. & PT. Palur Raya Dispute & 1998 & $\mathrm{~L}$ \\
\hline 27. & Kalimantan Peat Land Case & 1999 & $\mathrm{~L}$ \\
\hline 28. & Banger Case & 1999 & $\mathrm{~L}$ \\
\hline 29. & PT. Sumber Sehat (Kudus) & 1999 & NL \\
\hline 30. & Kanasritex (Semarang) & 1999 & NL \\
\hline 31. & PT. Kayu Lapis Indonesia (KLI) & 1999 & NL \\
\hline 32. & PT. Pura (Kudus) & 1999 & NL \\
\hline 33. & Way Seputih River & 2000 & $\mathrm{~L}$ \\
\hline 34. & Tawang Mas (Semarang) & 2000 & NL \\
\hline 35. & Pekanbaru Smog Case & 2000 & $\mathrm{~L}$ \\
\hline 36. & Kelian Equatorial Mining & 2001 & NL \\
\hline 37. & WALHI v PT. Freeport & 2001 & $\mathrm{~L}$ \\
\hline 38. & Transgenic Cotton Case & 2001 & $\mathrm{~L}$ \\
\hline 39. & PT. Lapindo Case & 2004 & $\mathrm{~L}$ \\
\hline 40. & MenLHut vs. PT. Bumi Hijau Lestari & 2015 & $\mathrm{~L}$ \\
\hline
\end{tabular}




\section{Diagram 1}

The Correlation of Climate Change and Community Conflict

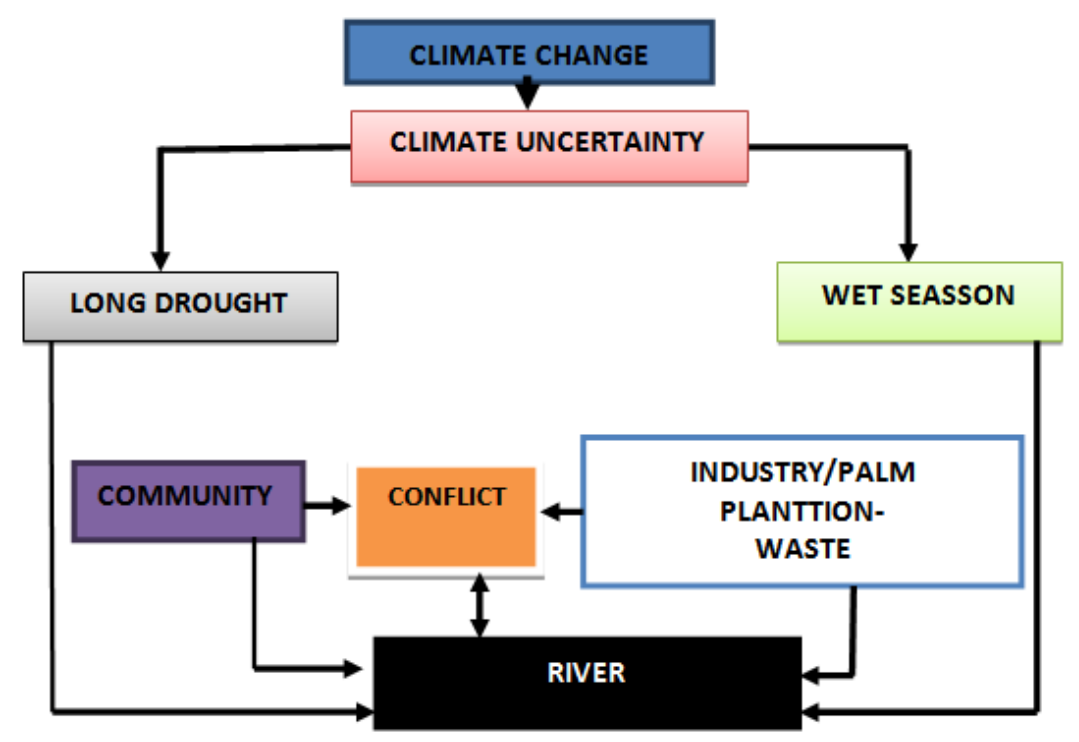

Figure 1: Resource Capture and Ecological Marginalization

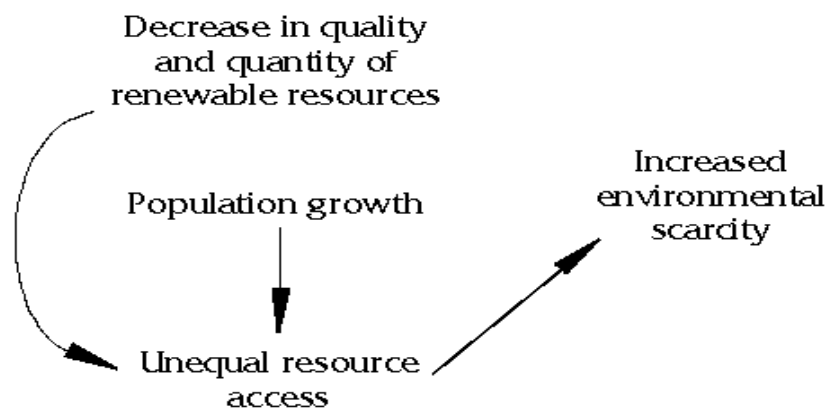

Resource Capture: Resource depletion and population growth cause unequal resource access.

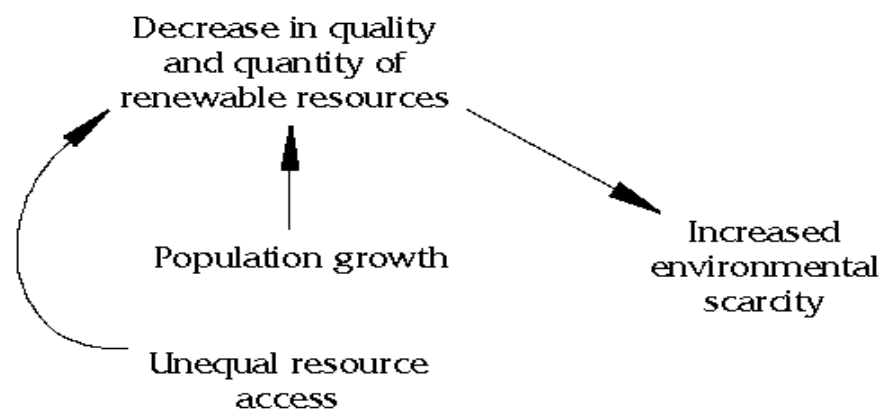

Ecological Marginalization: Unequal resource access and population growth cause resource degredation and depletion.

Source: Thomas F. Homer-Dixon,1994,Environmental Scarcities and Violent Conflict: Evidence from Cases,Peace and Conflict Studies Program, University of Toronto, International Security, Vol. 19, No. I, pp 5-40. 


\section{CONCLUSION}

From what had been discussed above, some conclusion will be drawn up here:

1. Up to 2009, the Indonesian Environmental Acts have undergone changes thrice $^{36}$ and within 27 years (19822009), there had been at least 40 environmental disputes between the communities and the industries and plantations. Pollution and environmental degradation were blamed to be the cause of conflict. Bringing the case to the court is in contradictory to the 2009 Law No. 23 on the Protection of and the Management of the Environment which requires the party to employ mediation first before deciding to bring their case to the court.

2. In environmental conflict, industries and palm plantations are blamed to be the contributor for environmental pollution and environmental degradation. Whilst many studies concluded that pollution is not the only factor to cause the conflict but also climate change may have also contributed to trigger the community environmental conflicts.Climate uncertainty may lead to long drought or long rainy season and change the cycle livelihoods of farmers and fishermen.

3. Geographically, Indonesia is one of the most vulnerable countries to the impact ofclimate change.Unfortunately, there is very little information one may obtain in regard with the correlation be-

36 The 1982 EMA No.4 on The Basics Provisions on Environmental Management replaced by The 1977 EMA No. 23 on Environmental Management and the last one is The 2009 EMA No. 32 of 2009 on The Protection and Environmental Management. tween the climate change and the community environmental disputes. The impact of the climate on the Indonesian territory may be inform of the decease of annual rain fall, the season uncertainty, water availability, sea-level rise, biodiversity and ecosystem services, human health and vulnerability and adaptation.

4. Although, the Government of Indonesia has anticipated the impact of the climate change by enacting several laws and regulations such as The 2004 Law No. 17 on the Ratification of the Kyoto Protocol to the United Nations Framework Convention On Climate Change (Kyoto Protocol Framework Convention on United Nations Regarding Climate Changes), The 2009 Law No. 32 on the Protection of and the Management of the Environment, The 2001 Government Regulation No. 4 on controlling the damage and pollution of the environment or relating to forest or land fires, The 2004 Law No. 19 on the Forestry. On the contrary, there is no study toexamine whether those laws and regulations are enforced well.

5. It is suggested that there must be some followed-up comprehensive studies in regrds with the climate change and the community environmental disputes.

\section{REFERENCES}

Allen, Petter T. 1998. "Pubic Participation in Resolving Environmetnal Disputes and the Problem of Representation," 9 Risk. p 297.

Angela Falconer, Skye Glenday, Anja Rosenberg and Jane Wilkinson. 2014. "Pemetaan Pendanaan Publik untuk Perubahan Iklim di Indonesia," Climate Policy 
Initiative, available from: http://climatepolicy initiative.org/publication/pemetaan-pendana an-publik-untuk-perubahan-iklim-di-indone sia. (retrieved: Dec 19, 2016).

Atapattu, Sumudu. 2002. "The Right to a Healthy Life or the Right to Die Polluted?, The Emergence of a Human Rights to a Healthy Environment Under International Law". 16 Tul. Envil. L. J.

Barnett, J. 2001. Security and Climate Change. Working Paper 7. Tyndall Centre for Climate Change Research, Norwich.

Brummans, Boris H. J. M., Linda L. Putnam, and Barbara Gray. 2008. "Making Sense of Intractable Multiparty Conflict: A Study of Framing in Four Environmental Disputes," Communication Monographs, Vol. 75 , Issue 1.

Bulland, Robert D. 2000. Dumping in Dixie: Race, Class, Environmental Quality, $3^{\text {rd }}$ Edition, West View Press.

Carpenter, S. L. 1982. "Managing Environmental Disputes". Peace \& Change, 8(2/3).

Crable, S. 1993.“ADR: A Solution for Environmental Disputes". Arbitration Journal, 48(1).

Crawfoot, James E., and Julia M. Wondolect. 1990. Community Involvement in Conflict Resolution, Washington DC, Covelo California: Island Press.

Darpo, J. 2009. Environmental Justice through Environmental Courts? Lessons Learned from the Swedish Experience. In Jonas Ebbesson and Phoebe Okowa (Ed), Environmental Law and Justice in Context, New York: Cambridge University Press.

Demin, C., and D. Zhengaia. 2008. "Environmental Rights: on the Perspective of Harmoniousevelopment between Human Beings and Nature", Law School of Chongqing University, Chongqing 400044, China 18 (1) China Population, Resources and Environment.
Desgagne, R. 1995. "Integrating Environmental Values into the European Human Rights Convention". The American Society of International Law, 89 A.J.I.L.

Gleditsch, N. P. 1998. "Armed Conflict and the Environment". Journal of Peace Research, 35(3).

Hill, B. et al. 2004. "Human Rights and the Environment: A Synopsis and Some Predictions," Geo. Int'l Envtl. L. Rev.16(359).

Homer-Dixon, Thomas F. 1994. "Environmental Scarcities and Violent Conflict: Evidence from Cases". Peace and Conflict Studies Program, University of Toronto, International Security, Vol. 19, No. I (Summer).

Jiang, Chong, and Linbo Zhang. 2015. "Climate Change and Its Impact on the EcoEnvironment of the Three-Rivers Headwater Region on the Tibetan Plateau, China," Int. J. Environ. Res. Public Health; doi:10.3390/ ijerph121012057.

Klare, M.T. 2001. Resource Wars: The New Landscape of Global Conflict. New York: Metropolitan.

Levy, M. 1995. "Is the Environment a Nnational Security Issue?". International Security, 20(2).

Liu, Yang; Saitoh, Sei-Ichi; Igarashi, Hiromichi; Hirawake, Toru. 2014. "The Regional Impacts of Climate Change on CoastalEnvironments and the Aquaculture of Japanese Scallops in Northeast Asia: Case Studies from Dalian, China, and Funka Bay, Japan," International Journal of Remote Sensing. Vol. 35 Issue 11/12.

Mahe, G.; Lienou, G.; Descroix, L.; Bamba, F.; Paturel, J. E.; Laraque, A.; Meddi, M.; Habaieb, H.; Adeaga, O.; Dieulin, C.; Chahnez Kotti, F.; Khomsi, K. 2013. "The Rivers of Africa: Witness of Climate Change and Human Impact on the Environment," Hydrological Processes. Vol. 27 Issue 15. 
Marcia, Creary. 2013. "Impact of Climate Change on Coral Reefs and the Marie Environment," UN Chronicle. Vol. 50 Issue 1.

Michael Case, Fitrian Ardiansyah, Emily Spector, Climate Change in Indonesia Implications for Humans and Nature, WWF(in http://assets.panda.org/downloads/ ino...) (Retrieved: January 12, 2017).

Nicholson, D.F. 2009. Environmental Disputes Resolution in Indonesia. Leiden: KITLV Press.

Pebriansyah Ariefana, "Dampak Perubahan Iklim di Indonesia yang Sudah Terasa" (30 Oct 2015), available from:http://www.suara. com/news/2015/10/30/060600/dampak-peru bahan-iklim-di-indonesia-yang-sudah-terasa. (retrieved: Jan 29, 2016).

Popovic, N.A.F. 1996. "In Pursuit of Environmental Human Rights: Commentary on the Draft Declaration of Principles on Human Rights and the Environment".27 Colum. Human Rights L. Rev.

PPN dan Bapenas. 2013. Rencana Akasi Nasional, Adaptasi Perubahan Iklim (RANAPI): perubahan Iklim dan Dampaknya di Indonesia.

Raleigh, Clionadh., Henrik Urdal. 2007. "Climate Change, Environmental Degradation and Armed Conflict," Political Geography, 26.

Rener, M. 1996. Fighting for Survival: Environment Decline, Social Conflict, the New
Age of Insecurity. Environmental Alert Series. New York: Norton.

Sahnoun, Mohammed. "Environnement et Développement", Revue Algérienne des Relations Internationales, No. 8, 1987, OPU, Algies in: Mrs. Fatma Zohra Kesentini Report in E/CN.4/Sub.2/1994/9 6 July 1994.

Straus, D. B. 1978. "Mediating Environmental Disputes", Arbitration Journal, 33(4).

Talbot, A. R. 2004. Settling Things: Six Case Studies inEnvironmental Mediation, Published by the Conservation Foundation and the Ford Foundation, $2^{\text {nd }}$ printing.

The 1982 Law No.4 on the Basic Provisions on Environmental Management.

The 1997 Law No. 23 on the Environmental Management.

The 2009 Law No. 32 on the Environmental Protection and Environmental Management.

Wentz, Jessica. 2015. "Assessing the Impact of Climate Change on the Built Environment," Environmental Law Reporter: News \& Analysis. Vol. 45 Issue 11. 